\title{
EVALUASI KEBIJAKAN SISTEM ZONASI DALAM PENERIMAAN PESERTA DIDIK BARU (PPDB) DI TINGKAT SEKOLAH MENENGAH PERTAMA NEGERI (SMPN) DI KABUPATEN PAMEKASAN
}

\author{
Hasbullah, Syaiful Anam \\ Fakultas Ilmu Administrasi, Universitas Madura \\ Email: ha2_qoe@yahoo.com
}

\begin{abstract}
This study focused on evaluating the implementation of the Zoning System policy, this is due to the response of the people in the research locations, namely in SMP 3 Pademawu Subdistrict, Pamekasan Regency, there are some who support and some complain and ultimately surrender to the policies that have government. The researcher used William Dunn's theory as a scalpel in analyzing the zonation system policy in receiving this student boarding ceremony. This study uses qualitative research. The location of the study was at the State Junior High School 3 Junior High School in Pademawu Subdistrict, Pamekasan Regency. The research subjects used purposive sampling. The researcher acts as an instrument that goes directly to the location of the study by using data collection techniques in the form of unattended interview techniques, guided free interviews (documentation interviews) and documentation techniques. The data analysis technique uses an interactive analysis model from Miles and Huberman which has three components, namely Data Collection, Data Condensation, Data Display and Conclusion Drawing / Verification. The results of this study are expected to contribute to the government in making and implementing policies specifically related to the implementation of the zoning system in the acceptance of new students in the future.
\end{abstract}

Keywords: Policy Evaluation; Zoning System; PPDB

Abstrak: Penelitian ini difokuskan pada evaluasi pemberlakuan kebijakan Sistem Zonasi, hal ini dikarenakan respon masyarakat di lokasi penelitian yaitu di SMPN 3 Kecamatan Pademawu Kabupaten Pamekasan berbeda-beda, ada yang mendukung dan ada yang mengeluhkan dan pada akhirnya pasrah pada kebijakan yang memang sudah ditetapkan oleh pemerintah. Peneliti menggunakan teori William Dunn sebagai pisau bedah dalam menganalisis kebijakan sistem zonasi dalam penerimaan pesera didik ini. Penelitian ini menggunakan penelitian kualitaif. Lokasi penelitian di Sekolah Menengah Pertama Negeri SMPN 3 Kecamatan Pademawu Kabupaten Pamekasan. Subyek penelitian penelitian menggunakan purposive sampling. Peneliti bertindak sebagai instrumen yang terjun langsung ke lokasi penelitian dengan menggunakan teknik pengumpulan data berupa teknik interview tidak terpimpin, interview bebas terpimpin (interview terpinpin) dan teknik dokumentasi. Teknik analisis data menggunakan model analisis interkatif dari Miles dan Huberman yang memiliki tiga komponen yaitu Data Collection, Data Condensation, Data Display dan Conclusion Drawing/Verification. Hasil penelitian ini diharapkan dapat berkontribusi bagi pemerintah dalam membuat dan menerapkan kebijakan khususnya terkait pemberlakuan sistem zonasi dalam penerimaan peserta didik baru di masa-masa mendatang.

Kata kunci: Evaluasi Kebijakan; Sistem Zonasi; PPDB 


\section{PENDAHULUAN}

Pemerintah Indonesia melakukan berbagai strategi dalam upaya meningkatkan kualitas dalam bidang pendidikan yaitu dengan menerbitkan peraturan Menteri pendidikan dan kebudayaan tertuang dalam Nomor 14 Tahun 2018 tentang Penerimaan Peserta Didik Baru mulai dari tingkat Dasar sampai Menengah Atas bagi sekolah-sekolah yang dilaksanakan dibawah kendali pemerintah daerah yaitu penerapan sistem zonasi. Sistem Zonasi di terapkan dalam rangka pemerataan pendidikan dan menghilangkan stratafikasi dalam dunia pendidikan.

Sedangkan sistem zonasi merupakan suatu bentuk pemantapan dan efiesnsi bagi masyarakat untuk memasukkan anaknya sesuai lokasi sekolasi dekat rumahnya, sebagaimana disebutkan dalam Permendikbud bagian keempat pasal Pasal 16 ayat (3) yang berbunyi: "Radius zona terdekat sebagaimana dimaksud pada ayat (1) ditetapkan oleh pemerintah daerah sesuai dengan kondisi di daerah tersebut berdasarkan: a. ketersediaan anak usia Sekolah di daerah tersebut; dan b. jumlah ketersediaan daya tampung dalam rombongan belajar pada masing-masing Sekolah, dan ayat (4) dalam menetapkan radius zona sebagaimana dimaksud pada ayat (3), pemerintah daerah melibatkan musyawarah/kelompok kerja kepala Sekolah.

Senada dengan i'tikad baik pemerintah terkadang tidak sepenuhnya berjalan mulus karena yang namanya kebijakan pasti akan menimbulkan pro dan kontra yaitu munculnya polemik di tengah masyarakat, munculnya sistem zonasi dalam penerimaan siswa baru di nilai merugikan oleh masyarakat karena tidak bisa menempatkan anaknya pada sekolah favorit atau unggul.

Kabupaten Pamekasan baru pada tahun 2018 ini memberlakukan sistem Penerimaan siswa baru berdasarkan lokasi siswa. Peneliti menjadikan Sekolah Menengah Pertama Negeri (SMPN) 3 Pademawu sebagai sampel dalam penelitian, hal ini didasarkan peneliti temukan dilapangan, sebagaimana yang diungkap oleh bapak imam musthofa (40 tahun) seorang kepala rumah tangga yang pada mulanya agak keberatan dengan sistem zonasi ini karena anaknya tidak bisa masuk pada sekolah yang sudah di idamkan. Sedangkan jika merunut pada kebijakan pemerintah anaknya harus sekolah di SMPN 3 Pademawu zonanya lebih dekat ke area tersebut.

\section{Kebjakan Publik}

Kebijakan publik adalah setiap keputusan yang dibuat oleh negara sebagai strategi untuk merealisasikan tujuan dari negara. Menurut Soenarko (2000:36) yaitu:

1. Kebijakan publik memiliki pengertian yang bersifat tetap, serta melekat pada seseorang yang tidak berubah kecuali adanya sebab untuk perkembangan;

2. Kebijakan publik suatu istilah yang menunjukkan adanya proses, karena merupakan hasil keputusan atau perbuatan yang mempunyai sifat untuk dilaksanakan;

3. Kebijakan publik merupakan tindakan yang dilakukan oleh instansi pemerintah untuk mencapai tujuan bersama demi kepentingan bersama, baik berupa undang-undang maupun peraturan-peraturan (Hayat, 2000:24);

4. Kebijkan publik dimungkinkan bersifat positif dalam arti merupkan pedoman tindakan pemerintah yang harus dilakukan dalam menghadapi suatu masalah tertentu, atau bersifat negatif dalam arti merupakan keputusan pejabat untuk tidak melakukan sesuatu (Wahab 2010 dalam Ramdhani, 2017: 3). 


\section{Evaluasi Kebijakan Publik}

Menurut Dunn (2000: 29) istilah evaluasi mempunyai arti yang berhubungan, "masing-masing menunjuk pada aplikasi beberapa skala nilai terhadap hasil kebijakan dan program. Evaluasi mencakup kesimpulan, klarifikasi, kritik, penyesuaian dan perumusan masalah kembali". Lebih lanjut dijelaskan bahwa istilah evaluasi dapat disamakan dengan penafsiran (appraisal), pemberian angka (rating) dan penilaian (assessment), kata-kata yang menyatakan usaha untuk menganalisis hasil kebijakan dalam arti satuan nilainya. Dalam arti yang lebih spesifik, evaluasi berkenaan dengan produksi informasi mengenai nilai atau manfaat hasil kebijakan (Dunn, 2000: 608).

Menurut Lester dan Stewart dalam Winarno (2012: 229) bahwa "evaluasi kebijakan meliki dua tugas utama yang berbeda antara lain: Pertama adalah untuk menentukan konsekuensi-konsekuensi apa yang ditimbulkan oleh suatu kebijakan dengan cara menggambarkan dampaknya. Sedangkan tugas kedua adalah untuk menilai keberhasilan atau kegagalan suatu kebijakan berdasarkan standart atau criteria yang telah ditetapkan sebelummya.

Sedangkan Anderson dalam menurut Winarno (2012: 229) suatu kegiatan yang menyangkut estimasi atau peneilaian kebijakan mencakup substansi, imlementasi dan dampak". Namun demikian, ada beberapa ahli yang mengatakan sebaliknya bahwa evaluasi bukan merupakan tahap akhir dari proses kebijakan publik. Pada dasamya, kebijakan publik dijalankan dengan maksud tertentu, untuk meraih tujuan-tujuan tertentu yang berangkat dari masalah-masalah yang telah dirumuskan sabelumnya.

Nugroho dalam Anggraeni $(2012,121)$ mengelompokkan evaluasi menjadi tiga, yaitu: a. Evaluasi administratif, yang berkenaan dengan evaluasi sisi administratif-anggaran, efisiensi biaya-dari proses kebijakan di dalam pemerintah yang berkenaan dengan: 1) effort evaluation, yang menilai dari sisi input program yang dikembangkan oleh kebijakan 2) performance evaluation, yang menilai keluaran (output) dari program yang dikembangkan oleh kebijakan 3) adequacy of performance evaluation atau effectiveness evaluation, yang menilai apakah program dijalankan sebagaimana yang sudah ditetapkan 4) efficiency evaluation, yang menilai biaya program dan memberikan penilaian tentang keefektifan biaya tersebut 5) process evaluations, yang menilai metode yang dipergunakan oleh organisasi untuk melaksanakan program b. Evaluasi judicial, yaitu evaluasi yang berkenaan dengan isu keabsahan hukum tempat kebijakan diimplementasikan, termasuk kemungkinan pelanggaran terhadap konstitusi, sistem hukum, etika, aturan administrasi negara, hingga hak asasi manusia. c. Evaluasi politik, yaitu menilai sejauh mana penerimaan konstituen politik terhadap kebijakan publik yang diimplementasikan.

Evaluasi dilakukan karena tidak semua program kebijakan publik meraih hasil yang diinginkan. Seringkali terjadi, kebijakan publik gagal meraih maksud atau tujuan yang telah ditetapkan sebelumnya. Dengan demikian, evaluasi kebijakan ditujukan untuk melihat sebabsebab kegagalan suatu kebijakan atau untuk mengetahui apakah kebijakan publik yang telah dijalankan meraih dampak yang diinginkan. Dalam bahasa yang lebih singkat evaluasi adalah kegiatan yang bertujuan untuk menilai "manfaat" suatu kebijakan.

\section{Fungsi Evaluasi Kebijakan Publik}

Menurut Dunn (2000: 609) menjelaskan bahwa Fungsi evaluasi kebijakan publik yang pertama dan yang paling penting adalah evaluasi memberi informasi yang valid dan dapat dipercaya mengenai kinerja kebijakan. Kedua, evaluasi memberi sumbangan pada klarifikasi 
dan kritik terhadap nilai-nilai yang mendasari pemilihan tujuan dan target. Ketiga, evaluasi memberi sumbangan pada aplikasi metode-metode analisis kebijakan lainnya, termasuk perumusan masalah dan rekomendasi.

Sedangkan menurut Wahab (1997: 8) menjelaskan bahwa: Fungsi dari evaluasi kebijakan adalah sebagai sebuah instrumen rasional untuk meneliti kondisi-kondisi dan hasilhasil dari proyek, program pembangunan atau berbagai bentuk pemberian pelayanan kepada publik guna memperoleh informasi mengenai kinerja proyek atau program tersebut dari tangan pertama.

Berdasarkan pendapat di atas dapat disimpulkan bahwa evaluasi merupakan suatu proses kebijakan yang paling penting karena dengan evaluasi kita dapat menilai seberapa jauh kebutuhan, nilai dan kesempatan dengan melalui tindakan publik, dimana tujuan-tujuan tertentu dapat dicapai. Sehingga kepantasan dari kebijakan dapat dipastikan dengan alternatif kebijakan yang baru atau merevisi kebijakan

\section{Kriteria Evaluasi Kebijakan Publik}

Menurut Wahab (1997: 36) bahwa pengukuran terhadap efektivitas proyek hanya mungkin dilakukan kalau dokumen proyek tersebut menunjukkan hal-hal berikut:

a) Tujuan-tujuan proyek dirumuskan dengan jelas dan dalam bentuk pernyataan-pernyataan yang terukur (measurable). Jika misalnya karena satu dan lain hal pengukuran tersebut tidak mungkin dilakukan secara langsung, maka rencana proyek harus bisa menunjukkan dengan tepat lewat indikator-indikator nyang manakah pengukuran itu dapat dilakukan.

b) Pengukuran terhadap perbaikan kinerja organisasi dalam sebuah proyek yang dimaksudkan untuk pengembangan kelembagaan bukan hanya merupakan persoalan yang agak ilusif, tetapi juga sensitife.

c) Persoalan serius yang seringkali muncul ialah bahwa hasil akhir proyek merupakan proses negosiasi dan perumusan tujuan harus dikompromikan.

d) Evaluator kemungkinan juga menghadapi masalah bahwa atasannya mempunyai penafsiran berbeda terhadap tujuan proyek, sebagaimana halnya perbedaan penafsiran antara pelaksana proyek dengan evaluator sendiri.

Selanjutnya Wahab juga menjelaskan bahwa hasil akhir efektivitas proyek dapat diukur dengan persamaan berikut :

Efektivitas $=\frac{\text { Hasil }}{\text { Tujuan }}$

Dalam penerapannya, program atau kebijakan publik diperlukan adanya suatu kriteria untuk mengukur keberhasilan program atau kebijakan. Menurut Dunn, kriteria untuk mengukur keberhasilan tersebut adalah sebagaimana berikut ini: 
Tabel 2.1. Kriteria Evaluasi

\begin{tabular}{|l|l|l|}
\hline TipeKriteria & Pernyataan & Ilustrasi \\
\hline $\begin{array}{l}\text { Efektifitas } \\
\text { (Effectiveness) }\end{array}$ & $\begin{array}{l}\text { Apakah Hasil yang di inginkan telah } \\
\text { tercapai? }\end{array}$ & Unit pelayanan \\
\hline $\begin{array}{l}\text { Efisiensi } \\
\text { (Efficiency) }\end{array}$ & $\begin{array}{l}\text { Seberapa banyak usaha diperlukan } \\
\text { untuk mencapai hasil yang } \\
\text { diinginkan? }\end{array}$ & $\begin{array}{l}\text { Unit biaya } \\
\text { Manfaat bersih } \\
\text { Rasio biaya-manfaat }\end{array}$ \\
\hline $\begin{array}{l}\text { Kecukupan } \\
\text { (Adequacy) }\end{array}$ & $\begin{array}{l}\text { Seberapahjauhpencapaian hasil yang } \\
\text { diingin kan memecahkanmasalah? }\end{array}$ & $\begin{array}{l}\text { Biaya tetap (masalah tipe I) } \\
\text { Efektivitas tetap (masalah } \\
\text { tipe II) }\end{array}$ \\
\hline $\begin{array}{l}\text { Pemerataan } \\
\text { /Kesamaan } \\
\text { (Equity) }\end{array}$ & $\begin{array}{l}\text { Apakah biasa dan mafaat } \\
\text { didistribusikandengan merata kepada } \\
\text { kelompok yang berbeda? }\end{array}$ & $\begin{array}{l}\text { Kriteria Pareto } \\
\text { Kriteria kaldor-Hicks } \\
\text { Kriteria Rawls }\end{array}$ \\
\hline $\begin{array}{l}\text { Responsivitas (Res } \\
\text { ponsiveness) }\end{array}$ & $\begin{array}{l}\text { Apakah hasil kebijakan memuaskan } \\
\text { kebutuhan, preferensi atau nilai } \\
\text { kelompok-kelompok tertentu? }\end{array}$ & $\begin{array}{l}\text { Konsistensi dengan survai } \\
\text { warga negara }\end{array}$ \\
\hline $\begin{array}{l}\text { Ketepatan } \\
\text { (Appropriateness) }\end{array}$ & $\begin{array}{l}\text { Apakah hasil (tujuan) yang } \\
\text { diinginkan bener-bener berguna atau } \\
\text { bernilai? }\end{array}$ & Unit pelayanan \\
\hline
\end{tabular}

Sumber: Dunn (2000: 610)

Dari berbagai macam kriteri evaluasi tersebut. Maka peneliti kteriteria diatas. Karena Kegiatan evaluasi lebih terfokus pada kegiatan yang sedang dilaksanakan. evaluasi dilakukan dengan cara menggali untuk mendapatkan informasi secara regular berdasarkan kriteria tertentu, dengan maksud mengetahui apakah kegiatan yang sedang berlangsung sesuai dengan perencanaan dan prosedur yang telah disepakati. Criteria evaluasi kebijakan mencakup esensi aktivitas dan target yang ditetapkan pada perencanaan program. Apabila evaluasi dilaksanakan dengan baik akan bermanfaat dalam memastikan pelaksanaan kegiatan tetap pada jalurnya (sesuai pedoman dan perencanaan program). Juga memberikan informasi kepada pengelola program apabila terjadi hambatan dan penyimpangan, serta sebagai masukan dalam melakukan evaluasi.

Penilaian (evaluasi) merupakan tahapan yang berkaitan erat dengan kegiatan monitoring, karena kegiatan evaluasi dapat menggunakan data yang disediakan melalui kegiatan monitoring. Dalam merencanakan suatu kegiatan hendaknya evaluasi merupakan bagian yang tidak terpisahkan, sehingga dapat dikatakan sebagai kegiatan yang lengkap. Evaluasi diarahkan untuk mengendalikan dan mengontrol ketercapaian tujuan. Evaluasi berhubungan dengan hasil informasi tentang nilai serta memberikan gambaran tentang manfaat suatu kebijakan. Istilah evaluasi ini berdekatan dengan penafsiran, pemberian angka dan penilaian. Evaluasi dapat menjawab pertanyaan "Apa pebedaan yang dibuat” (Dunn: 2000).

Evaluasi bertujuan untuk mengetahui apakah program itu mencapai sasaran yang diharapkan atau tidak. Evaluasi lebih menekankan pada aspek hasil yang dicapai (output). Evaluasi baru bisa dilakukan jika program itu telah berjalan setidaknya dalam suatu periode (tahapan), sesuai dengan tahapan rancangan dan jenis program yang dibuat dalam perencanaan dan dilaksanakan.

\section{Implementasi Sistem Zonasi}

Menurut Undang-Undang Nomor 20 Tahun 2003 tentang pendidikan nasional, yang dimaksud pendidikan adalah usaha sadar dan terencana untuk mewujudkan suasana belajar 
dan proses pembelajaran agar peserta didik secara aktif mengembangkan potensi dirinya untuk memiliki kekuatan spiritual keagamaan, pengendalian diri, kepribadian, kecerdasan, akhlak mulia, serta keterampilan yang diperlukan dirinya, masyarakat, bangsa dan negara.

Dalam rangka mewujudkan tujuan pendidikan nasional tersebut di atas maka pemerintah melakukan berbagai upaya, tidak hanya pada saat pendidikan itu dilaksanakan akan tetapi mulai dari seleksi penerimaan peserta didik, pemerintah berupaya agar peserta didik mendapatkan haknya tanpa perlu merasa mendapat perlakuan diskriminatif.

Di dalam Permedikbud Nomor 14 tahun 2018 pasal 1 ayat (3) menjelaskan bahwa Penerimaan peserta didik baru (PPDB) adalah penerimaan peserta didik baru pada TK dan Sekolah. Selanjutnya dalam Pasal 2 ayat (1) dijelaskan bahwa tujuan PPDB adalah untuk menjamin penerimaan peserta didik baru berjalan secara objektif, transparan, akuntabel, nondiskriminatif, dan berkeadilan dalam rangka mendorong peningkatan akses layanan pendidikan.

Peserta didik adalah anggota masyarakat yang berusaha mengembnagkan potensi diri melalui proses pembelajaan yang tersedia pada jalur, jenjang, dan jenis pendidikan tertentu.

Sistem zonasi ialah tidak menekan pada nilai calon peserta didik namun pada jarak atau radius antara rumah siswa dengan sekolah, system ini merupakan bentuk penyesuaian kebijakan rayonisasi. Sistem zonasi ini bertujuan untuk:

1) mewujudkan pemerataan kualitas pendidikan di berbagai penjuru daerah Indonesia.

2) menghilangkan "stigma" yang terlanjur bergulir dalam masyarakat tentang pengelompokan sekolah yang dianggap unggulan dan tidak unggulan.

3) siswa yang memiliki kemampuan di atas rata-rata akan menyebar sesuai dengan zona yang ada di daerahnya masing-masing. Dengan ini pemerintah mengharapkan semua sekolah yang ada akan memiliki mutu dan kualitas yang sama.

\section{METODE PENELITIAN}

Penelitian ini menggunakan pendekatan penelitian deskriptif-kualitatif. Secara umum penelitian deskriptif lebih dimaksudkan untuk melakukan pengukuran terhadap fenomena sosial tertentu yang bertujuan untuk membuat deskripsi, gambaran secara sistematis, fakta dan hubungan antar fenomena. Nawawi $(1998 ; 64)$ merumuskan ciri-ciri pokok dari penelitian deskriptif adalah pertama; memusatkan perhatian pada masalah-masalah yang ada pada saat penelitian dilakukan. Kedua; menggambarkan fakta-fakta tentang masalah yang diselidiki sebagaimana adanya, diiringi dengan interpretasi yang kuat.

Dasar pertimbangan penulis menggunakan jenis ini karena penelitian ini sarat dengan analisis terhadap data-data yang ada bersifat interpretatif terhadap proyeksi kedepan yang sesuai dengan metode penelitian kulitatif. Melalui jenis ini diharapkan akan menghasilkan informasi bagi pembentukan pengetahuan baru dan kebenaran ilmiah yang bisa dipertanggungjawabkan. Oleh karena itu untuk mendapatkan hasil penelitian yang lebih mendalam peneliti mengambil jenis penelitian deskriptif-kualitatif.

Sebelum melakukan penelitian, peneliti terlebih dahulu mencari dan menetapkan informan. Sumber informasi penelitian ini ialah Kepala SMPN 3 pademawu, wali murid, Kepala Dinas Pendidikan \& Kebudayaan dan Dewan Pendidikan Kabupaten Pamekasan. Oleh karena itu dalam menentukan informan peneliti menggunakan metode:

1. Purposive sampling yaitu kepala desa, dan 3 orang wali murid, 1 orang sesepuh desa,

2. Incidental sampling yaitu beberapa warga desa sekitar sekolah SMPN 3 Pademawu dan Dinas Pendidikan \& Kebudayaan dan Dewan Pendidikan Kabupaten Pamekasan 
Ada dua macam teknik pengumpulan data yang digunakan dalam penelitian ini, yaitu :

a. Interview

Interview dilakukan dengan wawancara dan tanya jawab langsung dengan subyek penelitian maupun informan lainnya. Hal ini dilakukan untuk memperoleh informasi atau data secara lebih jelas dan mendalam. Dengan digunakannya interview ini peneliti akan dapat menggali apa yang diketahui dan dialami oleh seseorang yang diteliti, juga apa yang tersembunyi di dalam diri objek penelitian. Di samping itu apa yang ditanyakan kepada informan bisa mencakup hal-hal yang bersifat lintas waktu berkaitan dengan masa lampau, masa sekarang dan juga masa yang akan datang.

Interview menurut Sugiyono (2010:93) adalah sebagai pengumpulan data dengan jalan tanya jawab sepihak yang dikerjakan dengan sistematis berlandaskan dengan tujuan penyelidikan. Sementara menurut Moleong (2005:69), interiew atau wawancara adalah suatu percakapan dengan tujuan. Tujuan dilakukan wawancara untuk memperoleh konstruksi yang terjadi sekarang tentang orang, kejadian, aktivitas, organisasi, perasaan, motivasi, pengakuan, kerisauan dan sebagainya. Ditinjau dari jenisnya, interview dapat dibedakan menjadi:

1) Interiew tak terpimpin, yaitu tidak adanya kesengajaan pada pihak interview untuk mengarahkan tanya jawab kepokok-pokok persoalan yang menjadi titik fokus dari kegiatan penyelidikan.

2) Interview terpimpin, yaitu penginterview terikat oleh suatu fungsi bukan saja pengumpulan data melalui tanya jawab melainkan sebagai pengumpul data yang relefan terhadap maksud-maksud penyelidikan yang telah disediakan dengan masak sebelum kegiatan interview sebenarnya dijalankan.

3) Interview bebas terpimpin, yaitu menginterview membawa kerangka pertanyaanpertanyaan (frome work of question) untuk disajikan, tetapi cara bagaimana pertanyaanpertanyaan itu diajukan diserahkan kepada kebijaksanaan interview. Pedoman interview dalam penelitian ini juga digunakan sebagai instrumen penunjang. Kemudian jenis interview yang digunakan dalam penelitian ini adalah interview terpimpin, di mana pedoman interview telah dipersiapkan sebelumnya oleh penulis.

b. Dokumentasi adalah teknik pengumpulan data sekunder dengan cara mencari data dari sejumlah dokumen instansi yang dianggap penting dan mempunyai relevansi dengan masalah yang diteliti.

Dalam bukunya Lexy J. Moleong yang berjudul Metode Penelitian Kualititaf, analisis data menurut Patto adalah proses mengatur urutan data, mengorganisasikannya ke dalam suatu pola, kategori dan suatu uraian dasar. Sedangkan menurut "Matthew B Miles dan A Michael Huberman dalam Sugiyono (2010:16) analisis data terdiri dari tiga alur kegiatan, yaitu reduksi data, penyajian data dan penarikan kesimpulan atau Verifikasi. Tetapi sebelum dilakukan tiga alur analisis tersebut, dilakukan analisis pendahuluan yaitu pengumpulan data.

Setelah peneliti mengumpulkan sejumlah data yang berkaitan dengan Evaluasi kebijakan sistem zonasi dalam penerimaan peserta didik baru (PPDB) di tingkat sekolah menengah pertama negeri (SMPN) Di kabupaten pamekasan, maka segera peneliti menganalisis data-data tersebut. Teknik dalam penelitian ini bersifat deskriptif karena penelitian ini menganalisa suatu keadaan, penggunaan analisis deskriptif kualitatif dimulai dari analisis berbagai data yang terhimpun dari suatu penelitian kemudian bergerak ke arah pembentukan kesimpulan. Oleh karena itu analisis deskriptif ini dimulai dari klasifikasi data. 


\section{Gambar 2. Komponen-Komponen Analisis Data Model Interaksi}

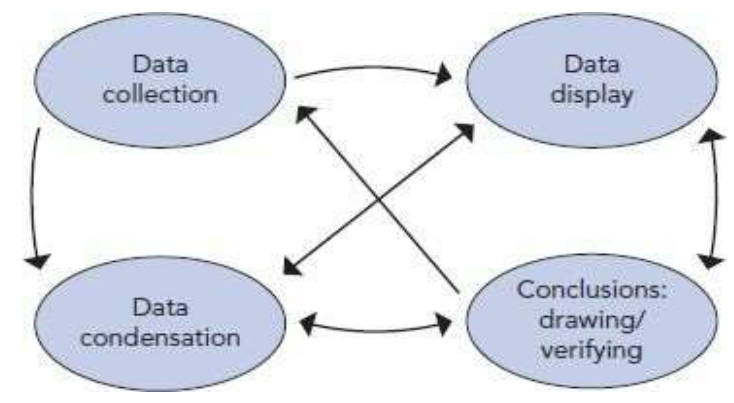

Sumber: Miles dan Huberman

Jadi dalam teknik analisa data yang penulis gunakan adalah meliputi:

1. Pengumpulan data (Data Colletion)

Data yang muncul berwujud kata-kata dan bukan rangkaian kata yang terkumpul dalam aneka cara (observasi, wawancara dan dokumentasi)

2. Reduksi data (Data Condensation)

Merupakan proses pemilihan, pemusatan perhatian pada penyederhanaan, pengabstrakan dan transformasi data "kasar" yang muncul dari catatan-catatan tertulis dilapangan.

3. Penyajian data (Data Display)

Sebagai sekumpulan informasi yang tersusun yang memberi kemungkinan adanya penarikan kesimpulan dan pengambilan tindakan.

4. Penarikan kesimpulan (Verifikasi Conclusion Drawing/Verification)

Data yang telah diperoleh dilapangan disajikan sedemikian rupa kemudian dilakukan analisis terhadap data tersebut untuk memperoleh hasil yang sebenarnya.

Sehingga dalam penelitian kualitatif, analisis datanya nanti akan lebih banyak didominasi oleh kata, kalimat dan ungkapan serta jarang sekali menggunakan data yang berupa angka. Meskipun demikian, hal ini tidak menutup kemungkinan ditampilkannya tabel untuk mendukung kelengkapan data dan kevalidan data.

Dalam metode penelitian deskriptif dengan pendekatan kualitatif maka metode analisisnya adalah metode analisis kualitatif. Dengan pertimbangan bahwa penelitian ini berusaha menggambarkan fenomena sosial yang terjadi dalam masyarakat yaitu tentang pelaksanaan sistem zonasi PPDB.

\section{HASIL DAN PEMBAHASAN}

Berdasarkan uraian beberapa teoritis yang terdapat dalam bab sebelumnya serta setelah dihubungkan dengan hasil penelitian (wawancara dan dokumentasi), maka sebelum ditarik kesimpulan perlu diadakan suatu pembahasan terlebih dahulu. Pembahasan tersebut adalah analisis mengenai Evaluasi Kebijakan sistem zonasi dalam penerimaan peserta didik baru (PPDB) di Tingkat Sekolah Menengah Pertama Negeri (SMPN) Di kabupaten pamekasan, yang mencakup evaluasi pelaksanaan kebijakan system zonasi di Kabupaten Pamekasan.

Evaluasi pelaksanaan kebijakan system zonasi dapat ditinjau dari hasil yang telah dicapai berbanding dengan tujuan dari program tersebut. Sebagaimana yang diungkapkan oleh Wahab (1997: 36) bahwa "efektivitas suatu program atau proyek dapat diukur dengan 
persamaan Efektivitas $=\frac{\text { Hasil }}{\text { Tujuan }}$ “ maka, untuk mengetahui apakah pelaksanaan kebijakan system zonasi tersebut telah efektif atau tidak dan terdapat kesalahan atau penyalahgunaan yang sudah ditetapkan dalam aturan Sistem Zonasi Penerimaan Peserta Didik Baru Sehingga dapat diperoleh gambaran mengenai pelaksanaan Sistem Zonasi Penerimaan Peserta Didik Baru di SMPN 3 Pademawu kabupaten pamekasan.

\section{Sosialisasi Sistem Zonasi Penerimaan Peserta Didik Baru (PPDB)}

Berdasarkan observasi dilapangan sosialisasi diberikan dengan cara mengumpulkan masing-masing kepala desa dan kepala sekolah dasar disekitar lokasi untuk diberikan penjelasan mengenai proses Sistem Zonasi terutama terkait radius tau jarak tempuh rumah siswa dengan sekolah, walaupun demikian masih ada beberapa kendala, hal ini dikarenakan kurangnya sosialisasi ataupun pemantapan yang disampaikan dan kurang di follow up oleh pihak yang terlibat dalam Sistem Zonasi Penerimaan Peserta Didik Baru.

Dari kurangnya bentuk sosialisasi yang diberikan dapat menimbulkan dampak kecurigaan masyarakat terhadap aparatur penyelenggara rastra, karena dengan memberikan sosialisasi yang lebih luas dapat menunjukkan bahwa semua unsur yang terlibat dalam suksesi sistem zonasi PPDB lebih transparan menjalankan kegiatannya.

\section{Pelaksanaan Sistem Zonasi PPDB}

Pelaksanaan Sistem Zonasi Penerimaan Peserta Didik Baru (PPDB) sampai ketitik distribusi belum sesuai yang diharapkan oleh permendikbud nomer 14 tahun 2018 dan Sekolah menengah pertama (SMPN 3) pademawu yang notabene sekolah yang berada dilokasi ujung utara kabupaten pamekasan. Dari hasil wawancara saya dilapangan kepala sekolah SMPN 3 pademawu belum mendapatkan dampak positif terutatam dalam pemerataan siswa. Sehingga masih banyak ditemukan sekolah lain yang tidak menggunakan sistem zonasi dalam PPDB Karena kurang pengawasan dan sanksi tegas oleh pemerintah kabupaten pamekasan.

\section{Pemantauan dan Pengaduan Sistem Zonasi PPDB}

Berdasarkan penelitian yang saya lakukan dilapangan bahwa menurut beberapa narasumber kebayakan keluhan yang disampaikan seputar pemahaman tentang batasan zonasi, kurangnya sosialisasi yang diberikan melalui kepala desa dan kepala sekolah. Jika hal ini dibiarkan akan berdampak terjadinya Mis Understanding ditengah masyarakatdan kesenjangan yang berbentuk kastanisasi.

Hal ini dikarenakan tidak adanya lembaga atau tim pengawas yang dikhususkan untuk memantau mengawasi pelaksana Sistem Zonasi PPDB tetapi solusi untuk memecahkan permasalahan, agar dalam pelaksanaannya tidak menimbulkan sesuatu yang negatif. Berdasarkan hasil wawancara dilapangan menjelaskan bahwa evaluasi yang dilakukan pihak pemerintah biasanya terkait masalah keluhan dari masyarakat terkait permasalahan pelaksanaan sistem zonasi PPDB. Dari hasil wawancara di atas bahwa para Kepala sekolah dan perangkat Desa dalam melakukan Implementasi Kebijakan sistem zonasi PPDB di kabupaten pamekasan memberikan pelaksanaan sebaik mungkin terhadap masyarakat. sehingga pemerataan siswa baru bisa terlaksana sesuai permendikbud nomor 14 tahun 2018 . 


\section{KESIMPULAN}

Berdasarkan hasil penelitian dan pembahasan yang sudah dijelaskan maka dapat di simpulkan, sebagai berikut:

1. Pelaksanaan penerimaan peserta didik baru sistem zonasi di Kabupaten Pamekasan, yaitu:

a. Dalam pelaksanaan sistem zonasi terhadap PPDB di kabupaten Pamekasan masih mengacu pada Permendikbud No. 14 Tahun 2018 karna belum adanya petunjuk teknis pemerintah daerah .

b. Petunjuk teknis pelaksanaan PPDB yang memuat sistem zonasi mengatur tentang Pelaksanaan PPDB dengan memprioritaskan calon siswa yang berdomisili pada radius zona terdekat dengan kuota $90 \%$ tetapi sekolah wajib menerima $20 \%$ keluarga dengan ekonomi tidak mampu dari $90 \%$ dari total kuota penerimaan, kemudian 5\% dari Pemindahan KK dengan alasan Khusus dan 5\% dari calon siswaberprestasi.

c. Pelaksaanaan PPDB sistem zonasi jenjang SMP melalui kriteria urutan prioritas yaitu radius zona kemudian nilai hasil ujian yang tertera dalam Ijazah ataupun Surat tanda tamat belajar. Penerimaan jenjang SMP diberikan penskoran atau tambahan nilai terhadap calon siswa yang berprestasi dibidang akademik atuapun non akademik.

d. Petunjuk teknis PPDB Kabupaten Pamekasan juga mengatur tentang rombongan belajar setiap sekolah untuk jenjang SMP.

2. Faktor yang menjadi bahan evaluasi oleh pemerintah daerah sebagai berikut:

a. Belum adanya petunjuk teknis mengenai Pelaksanaan PPDB sistem zonasi.

b. Belum maksimalnya pelayanan terhadap masyarakat dalam pelaksanaan PPDB seperti sosialisasi mengenai ketentuan radius zona atau yang disebut dengan sistem zonasi.

c. Belum adanya pemerataan tenaga pengajar dan tenaga administrasi serta sarana dan prasarana demi tercapainya pemerataan mutu pendidikan.

d. Masih kurangnya pengawasan oleh Dinas Pendidikan dan Kebudayaan Kabupaten Pamekasan terhadap sekolah dalam pelaksanaan PPDB sistem zonasi dan tidak adanya tindakan tegas seperti sanksi pidana oleh aparatur yang berwenang kepadaoknumoknum yang melakukan pelanggaran karna sejauh ini pelanggaran-pelanggaran tersebut hanya dijatuhkan sanksi administratif.

\section{DAFTAR PUSTAKA}

Anggraeni, Ratih dkk. 2012. Jurnal Ilmiah Administrasi Publik. Vol I. No.1, Malang: Universitan Brawijaya

Dunn, Willian N.2000. Pengantar Analisis Kebijakan Publik. Edisi Kedua. Yogyakarta: Gajah Mada University Press.

Hayat. 2018. Kebijakan Publik: Evaluasi, Remormasi Dan Formulasi. Malang: Intrans Publishing.

Moleong, Lexy J. 2005. Metodologi Penelitian Kualitatif. Bandung: PT. Remaja Rosda Karya.

Nawawi, Hadari. 1995. Pengawasan Melekat Di Lingkungan Aperatur Pemerintah. Cetakan Kelima. Jakarta: Erlangga.

Peraturan menteri pendidikan dan kebudayaan Nomor 14 Tahun 2018 Tentang Sistem Zonasi Penerimaan Peserta Didik Baru (PPDB).

PP Nomor 47 Tahun 2008 tentang Wajib Belajar

Ramdhani, A. dan Ali R. M. 2017. Konsep umum Pelaksanaan Kebijakan. Bandung

Soenarko, SD. 2003. Public Policy: Kebijaksanaan Pemerintah. Surabaya: Airlangga Universitas Press. 
Solichin, Abdul Wahab. 1997. Analisis Kebijakan Publik. Cet. Pertama. Malang: IKIP Malang. Sugiyono, 2015. Metode Penelitian Bisinis Pendekatan Kuantitatif, Kualitatif Dan R\&D; Bandung: Alfabeta.

Undang-Undang RI Nomor 20 tahun 2003 tentang SISDIKNAS

Winarno. 2012. Kebijakan Public : Toeri, Proses, Dan Studi Kasus. Yogyakarta: CAPS 